Zabytkoznawstwo i Konserwatorstwo XLIV, Toruń 2013

Tatiana Basaniec*, Dariusz Markowski**

* historyk sztuki

** Zakład Konserwacji i Restauracji Sztuki Nowoczesnej WSP UMK

\title{
„Portret w twierdzy” \\ (o nieznanym obrazie A. I. Korzuchina)
}

\section{Wstęp}

X

$W$ przez prywatnego kolekcjonera malarstwa obraz z przedstawieniem zamkniętej w celi zasmuconej młodej dziewczyny. Obraz wykonany został na płótnie o wymiarach $72 \times 52 \mathrm{~cm}$, sygnowany i datowany przy prawej krawędzi obrazu, pośrodku - „Корзухинъ 1875” - nazwisko w języku rosyjskim, cyrylica.

Aleksiej Iwanowicz Korzuchina (1835-1894), znany w przeszłości malarz, dziś trochę zapomniany, nadal należy do znaczących malarzy rosyjskich, podejmujących głównie tematykę rodzajową i malarstwo portretowe. Analizowany obraz należy do reprezentacyjnego nurtu XIX-wiecznego malarstwa rosyjskiego oscylującego w tematyce równości społecznej oraz upadku feudalizmu.

Obraz został poddany szczegółowej analizie zarówno przez historyka sztuki, jak i konserwatora technologa, analizującego budowę, jego technikę i technologię, które pozwoliły „Portret w twierdzy” (tytuł obrazu umowny - T. B.) uznać za autentyczne dzieło Korzuchina. 


\section{Aleksiej Iwanowicz Korzuchin na tle XIX-wiecznego malarstwa rosyjskiego}

Przed przystapieniem do szczegółowego omówienia obrazu należałoby scharakteryzować jego autora - Aleksieja Iwanowicza Korzuchina. Artysta urodził się w 1835 roku na Uralu, w rodzinie przemywacza złota Uktusskiego Przedsiębiorstwa Poszukiwawczego (Jekaterinburg). Od najmłodszych lat wykazywał zdolności oraz chęć do malowania, a pierwsze swoje dzieła tworzył, będąc nastolatkiem. Chęć bycia artystą sprawiły, że Korzuchin w roku 1858 wstapił do Petersburskiej Akademii Sztuk Pięknych.

Uczestnicząc w zajęciach, artysta zdawał sobie sprawę z coraz silniej zarysowujących się sprzeczności pomiędzy kształceniem akademickim a dochodzącymi do głosu nowymi oczekiwaniami artystycznymi na gruncie przemian społecznych, co niekiedy rodziło poważne konflikty $z$ administracja Akademii. Niezgoda z panującym systemem kształcenia wynikała z sympatii do idei demokracji oraz radykalnych reform politycznych, o czym marzyła część społeczeństwa rosyjskiego.

Następstwem narastających konfliktów było podpisanie przez 14 uczniów Akademii w tym Korzuchina listu protestacyjnego odmawiającego udziału w konkursach, w których mieli w swoich pracach podejmować nie aktualne społecznie tematy. Wynikiem ,buntu” młodych było opuszczenie przez nich Akademii, stworzenie Zespołu Artystów (1863-1871) i praca na rzecz utworzenia Koleżeństwa Przemieszczanych Wystaw ${ }^{1}$ (1870-1922). Korzuchin nigdy jednak nie został aktywnym członkiem Koleżeństwa, odmawiając eksponowania swoich dzieł w wystawach organizacji. W 1872 roku ,jako nie stawiający się ze swoimi dziełami” został wykluczony z Ko-

\footnotetext{
1 „Spółdzielnia Malarzy” - twórcza i absolutnie niezależna od oficjalnej Akademii komercyjna organizacja artystów z Petersburgu, powołana w celu „otrzymania zysku i wspólnej pomocy”. Towarzystwo Wystaw Przemieszczalnych - niezależna organizacja twórcza, rozpoczęła demokratyzację rosyjskiej sztuki. Jej ideowo-estetyczne podwaliny to przeciwstawienie się akademizmowi, ukazywanie środkami malarskimi panujących wad społecznych oraz ścisłe łączenie artystów z narodem.
} 
leżeństwa. Taka była formalna przyczyna zerwania kontaktów z organizacja, prawdziwa jednak tkwiła w braku w jego twórczości wyraźnego protestu społecznego, deklarowanego przez „przemieszczeńców” jako podstawy ich działalności twórczej oraz nadal silne przekonania do akademickiego kształcenia artystycznego.

Artysta, dobrze znając cechy wzajemnych relacji ludzi swojego otoczenia oraz „zwyczaje” naradzającej się burżuazji, odbierał życie nie z pozycji krytyka, a opisującego ludzki byt. W jego obrazach nie znajdujemy treści obciążających, wręcz odwrotnie, zawsze odczytywane jest współczucie, proste ludzkie rozumowanie problemów oraz dążeń narodu. Twórczość Korzuchina to przykład artystycznego przedstawiania tematów realistycznych i scenek z życia narodu, a nie podkreślanie istniejących wad społecznych. Skomplikowane relacje artysty z przedstawicielami Koleżeństwa znalazły odzwierciedlenie na poziomie etycznego odbioru uczuć życiowych, w których polityczne, społeczne oraz ideowe przesłanki nie odgrywały praktycznie żadnej roli.

Jak łatwo zauważyć, w artyście dokonała się swoista przemiana od młodego człowieka, dla którego najistotniejsze jest pragnienie zmian społecznych, radykalizm ideowy i myślowy, do osoby dojrzałej w sposób przemyślany podchodzącej do swojej twórczości oraz roli artysty w społeczeństwie. Należy jednak zaznaczyć, że nie będąc członkiem Koleżeństwa, Korzuchin podzielał priorytety estetyczne kolegów i pochwalał ich ścisłe powiazanie $z$ narodem.

\section{„Portret w twierdzy” - analiza stylistyczna}

Przedstawiona postawa artysty nie jest bez znaczenia przy analizowaniu obrazu „Portret w twierdzy, w którym artysta operuje nie tylko środkami malarskimi, ale i emocjonalno-obrazowymi, tworząc jego fabułę. Mamy tutaj opowieść o dramatycznym losie rosyjskiej kobiety, którą skomplikowana sytuacja życiowa doprowadziła do uwięzienia i osamotnienia.

Tematyka aresztowań i uwięzień w obrazach artystów rosyjskich epoki „przemieszczeńców” była często podejmowana, chociaż każdy z nich w sposób indywidualny podchodził do ukazania niełatwej przecież fabu- 
ły. Przykładami mogą być obrazy: K. D. Flawickiego „Księżniczka Tarakanowa” (1868), N. D. Jaroszenki „Wszędzie życie” (1888), W. I. Jakobiego „Postój aresztantów” (1831), czy N. A. Kasatkina „Na korytarzu sądu okręgowego" (1897).

W odróżnieniu od wymienionych obrazów w portrecie A. I. Korzuchina brakuje jednak patosu, tragicznego przeżywania losu, ukazania sytuacji bez wyjścia. Autor w sposób bezpośredni opisuje zdarzenie, które przekazywane jest widzowi tylko jako konstatacja uwięzienia w twierdzy, za którym w sposób oczywisty kryje się życiowy dramat młodej dziewczyny i poddanie losowi. Mimo braku pogłębionej charakterystyki psychologicznej osoby portretowanej, w ogólnym nastroju kompozycji odczuwalne są motywy współczucia, zaangażowanego i głębokiego przenikania do ukazanej przez artystę sytuacji.

Charakteryzując bohaterkę obrazu, można przyjąć, że mamy do czynienia z prostą kobieta z ludu, na co moga wskazywać okragła twarz, lekko spuchnięte powieki i perkaty nos. Rozplecione włosy warkocza spadaja na ramiona i plecy. Postać ubrana jest skromnie. Bezwolnie opuszczone na kolana ręce z zaczerwienionymi lekko nabrzmiałymi palcami mogą wskazywać na osobę praczki, co potwierdzałoby status społeczny dziewczyny. A jednak bez względu na tak wyraźny kontekst „bohaterki z narodu” w jej wizerunku jest coś, co zmusza odbierać go bez potępienia, wręcz przeciwnie, z zaciekawieniem odkrywamy jej kobiecość i wręcz swoiste piękno. $\mathrm{Na}$ szczególną uwagę zasługuje mistrzowsko oddany spokojny, skierowany w stronę okna wzrok aresztowanej. Dalej, płynnie ślizgająca się linia rąk z intrygującym wgłębieniem na prawym łokciu, odsłonięte ramiona i pierś, przysłonięte białą bluzką z obszernym dekoltem. Swoistej atrakcyjności „narodowej piękności” nie ujmują srogie ściany twierdzy, złowieszcza krata okna, martwa natura z metalowym kubkiem i kawałkiem czarnego chleba na starym więziennym stole. Świadomym zabiegiem artystycznym w obrazie jest zestawienie obok siebie martwego, surowego i ubogiego wnętrza z postacia żywej pięknej kobiety. Takie rozwiązanie, będące symbolem nieprzewidywalnego losu, w sposób oczywisty wywołuje u obserwatora dramatyczne poczucie życia i czasu. Jest to swoista walka artysty ze sobą i swoimi przeżyciami, artysty pozostającego pod wpływem 
akademizmu, dla którego główną zasadą jest ukazanie piękna wywołującego uczucie, w tym także współczucie. Należy zauważyć, że w malarstwie A. I. Korzuchina, w jego licznych portretach oraz kompozycjach rodzajowych, nie spotykamy ukazywania nagiego ciała. Jednak w rozpatrywanym obrazie przedstawiono odsłonięte częściowo ramiona i piersi (głęboki dekolt). Przez ich akcent wizualny wyłania się cały urok kobiecego piękna, jej zmysłowość, pozwalające odbierać bohaterkę obrazu jako postać pozytywna. Kobieta z obrazu Korzuchina jawi się nam niczym postać Katarzyny Izmajłowej z dramatu N. S. Leskowa „Lady Makbet M-ceńskiego powiatu”, która godząc się na uwięzienie, pragnęła własnym życiem zapłacić za zdradę ukochanego mężczyzny.

Podkreślając widoczny w obrazie nurt akademizmu, należy zaznaczyć użycie w nim przez artystę niemal wszystkich chwytów malarskich praktykowanych w kształceniu akademickim. Mamy tutaj gładko z partiami laserunkowymi opracowana powierzchnię malarską oraz światłocieniowy modelunek. Widoczne jest budowanie cieniem przestrzeni wnętrza w zestawieniu $\mathrm{z}$ intensywnym światłem padającym $\mathrm{z}$ okna na odsłonięte części ciała. Artysta zastosował nawet umiejętność „korygowania” twarzy miękkim różowym „podmalowaniem” i jasnymi odblaskami warg oraz końcówki nosa. Bliski akademizmowi jest także sposób namalowania szat, w szczególności głębokie fałdy bluzy oraz jej kontrast kolorystyczny z granatową spódnica. W analizowanym „Portrecie” obok cech malarstwa akademickiego widoczne są również cechy nowego malarstwa, które pojawiło się w sztuce rosyjskiej w połowie XIX wieku, w schematycznie potraktowanym wnętrzu, zanurzonym fragmentami w głębokim cieniu oraz oczywiście w wyborze samej postaci bohaterki - dziewczyny z ludu. Rozpatrując szczegóły opisywanego portretu, odnajdujemy w nim szereg różnic w porównaniu $\mathrm{z}$ innymi, charakterystycznymi portretami artysty, ukazującymi znane postacie w statycznej, akademickiej kompozycji. „Portret w twierdzy” jest obrazem rodzajowym, w którym głównym bohaterem nie jest osoba historyczna, a postać zbiorowa, literaturowo uogólniona, podporządkowana podstawowej fabule i głównej idei dzieła. Portretowana występuje jako symbol, w którym odnajdujemy zarówno piękno, jak i dramat życia tak dobrze znane samemu artyście i czasom, w których żył. 


\section{„Portret w twierdzy” - badania i konserwacja}

\section{Stan zachowania i przyczyny zniszczeń}

Stan zachowania obrazu przed pracami konserwatorskimi oceniono jako dobry. Obraz był w przeszłości konserwowany, został zdublowany na nowe płótno i naciagnięty na wtórne krosna malarskie, fazowane z klinami. Format obrazu uległ częściowo zmniejszeniu, co potwierdzała obecność warstwy malarskiej na obecnych krajkach. Zaobserwowano drobne ubytki zaprawy, widoczne na krajkach, a szczególnie wzdłuż krawędzi załamań płótna mocowanego do krosien. Wtórne spękania warstwy malarskiej widoczne szczególnie w partiach karnacji (twarzy i szyi) malowanych grubo położoną farba, pokrywały się z ubytkami zaprawy. Prawdopodobnie sposób modelowania karnacji, polegający na kilkakrotnym nakładaniu farby, a przez to stworzeniu partii grubszej i mniej elastycznej w odniesieniu do pozostałych partii obrazu, był przyczyna powstania spękań. Na licu obrazu zaobserwowano również odciśnięta fakturę płótna dublażowego, znacznie grubszego od płótna oryginalnego. Niepożądany efekt odciśnięcia splotu płótna na licu nastapił na skutek przeprowadzenia zabiegu dublażu.

\section{Badania budowy technicznej i technologii obrazu²}

Dokonując analizy badawczej obrazu, przyjęto następująca metodykę identyfikacji materiałów ${ }^{3}$ :

- analiza mikroskopowa przekroju poprzecznego w świetle ViS i UV

- reakcje na przekrojach

- analiza kroplowa

2 Zob. D. Markowski, Analiza badawczo-konserwatorska obrazu „Księničkea Tarakanowa”, maszynopis, 2006

3 Zdjęcia przekroju stratygraficznego pobranej próbki wykonała dr Zuzanna Rozłucka z ZKMiRzP UMK, rentgenowską analizę fluorescencyjną pigmentów wykonał mgr Adam Cupa z ZTiTM UMK. 
— analiza mikrokrystaloskopowa

- analiza termiczna

- analiza spektralna XRF

Dodatkowo wykonano szczegółową analizę lica i odwrocia obrazu w świetle ViS, UV (ultrafiolet) ${ }^{4}$ i IR (podczerwień) ${ }^{5}$.

$\mathrm{Na}$ podstawie wykonanych badań można wysunąć następujące wnioski:

Obraz namalowany został na płótnie lnianym, nabitym na wtórne krosna malarskie, drewniane, fazowane i ruchome. Płótno przeklejone zostało klejem glutynowym. Zaprawa jest białoszara, emulsyjna (spoiwo: klej glutynowy, olej; wypełniacz: biel cynkowa - $\mathrm{ZnO}$ z niewielkim dodatkiem czerni żelazowej).

\section{Warstwa malarska}

Obraz został namalowany w technice wielowarstwowej. Kompozycja tworzy układu, w którym granica pomiędzy namalowana postacią a tłem w partiach cienia została niemal zatarta. Partie światła (karnacja, szaty) stanowią wyraźny kontrast dla ciemnych monochromatycznych partii obrazu w tym tła. Użyte w opracowaniu rozbielone szarości podkreślają zawężoną kolorystykę obrazu, wyraźnym akcentem barwnym jest tutaj jedynie dolna partia szaty (namalowanej w kolorze błękitnym) oraz czerwono-brązowe akcenty na oświetlonej partii ściany pomieszczenia.

Daje się zaobserwować specyficzny sposób malowania polegający na podnoszeniu świateł poprzez rozbiały, kładzione w kilku warstwach, two-

4 Wyraźne, mleczne i chłodne świecenie warstwy werniksu może świadczyć o pokryciu obrazu warstwą werniksu syntetycznego, werniks naniesiono pędzlem dość nierównomiernie. Na zdjęciu w UV widoczne również liczne ingerencje konserwatorskie, szczególnie w dolnej partii obrazu, co podyktowane jest najbardziej rozległymi w tym miejscu ubytkami warstwy malarskiej prawdopodobnie wraz z zaprawą. Można przypuszczać, że ubytki w dolnej partii obrazu powstały na skutek zawilgocenia płótna podczas niewłaściwego przechowywania obrazu. Drobne uzupełnienia widoczne również w partii tła oraz miejscach ubytków powstałych wzdłuż odciśnięcia się wewnętrznych krawędzi krosien. Nie stwierdzono odmiennego świecenia występującej przy prawej krawędzi obrazu, pośrodku sygnatury „Корзухинъ 1875”.

5 Analiza w IR potwierdziła wtórne ingerencje konserwatorskie, szczególnie w dolnej partii obrazu w tym dolnej części rąk. Wykluczono również wtórne wykonanie sygnatury. 
rzących wyraźną fakturę warstwy. Obraz w zamierzeniu artysty ograniczony w tonacji z wyraźną dominacją chłodów i barw srebrzystych.

Do namalowania obrazu artysta użył m.in. bieli ołowianej $-2 \mathrm{PbCO}_{3} \times \mathrm{Pb}(\mathrm{OH})_{2}$, żółcieni kasselskiej $-\mathrm{PbCl}_{2} \times 7 \mathrm{PbO}$, czerwieni żelazowej - $\mathrm{Fe}_{2} \mathrm{O}_{3}$, czerwieni chromowej - $\mathrm{PbCrO}_{4}$ x $\mathrm{PbO}$, błękitu pruskiego - $\mathrm{Fe}_{4}\left[\mathrm{Fe}(\mathrm{CN})_{6}\right]_{3}$ i czerni żelazowej.

\section{Prace konserwatorsko-restauratorskie ${ }^{6}$}

Celem prac konserwatorskich było przywrócenie pełnej wartości ekspozycyjnej obrazu. W pierwszej kolejności po zabezpieczeniu lica obraz rozdublowano i oczyszczono odwrocie z masy dublażowej. Po zdjęciu zabezpieczeń lico oczyszczono z zabrudzeń powierzchniowych. Usunięto wtórny pociemniały i zażółcony werniks oraz olejne uzupełnienia i przemalowania warstwy malarskiej (obraz wymagał usunięcia rozległych przemalowań głównie w dolnej jego partii).

Przeprowadzono zabieg konsolidacji warstwy malarskiej na stole próżniowym. Ubytki zaprawy uzupełniono białym kitem emulsyjnym. Ponieważ postanowiono przywrócić pierwotny format obrazu (powiększyć o fragmenty warstwy malarskiej zachodzące na krajki), konieczne było powiększenie krajek, które wzmocniono poprzez ich poddublowanie pasami płótna lnianego.

Obraz nabito na nowe, drewniane, ruchome i fazowane krosna z klinami.

Po zawerniksowaniu lica werniksem retuszerskim wykonano uzupełnienia ubytków warstwy malarskiej farbami żywicznymi, imitatorsko. $\mathrm{Na}$ koniec założono warstwę werniksu końcowego, błyszczącego i oprawiono obraz w ramę.

W olbrzymim dorobku artystycznym Korzuchina, który w dużej mierze znajduje się w zbiorach muzealnych Rosji ${ }^{7}$, nie odnaleziono prac bli-

6 Zob. D. Markowski, Dokumentacja prac konserwatorsko-restauratorskich obrazu olejnego na plótnie Aleksieja Korzuchina „Księzniçka Tarakanowa”, maszynopis, 2007.

7 Największy zbiór malarstwa A.I. Korzuchina znajduje się w Muzeum Rosyjskim (St. Petersburg) oraz w Państwowej Tretiakowskiej Galerii (Moskwa), obrazy przechowywane są również $\mathrm{w}$ wielu zbiorach muzealnych byłego ZSSR. 
skich tematowi „Portretu w twierdzy”. Odnaleziony obraz z wizerunkiem młodej uwięzionej kobiety jest dziełem odosobnionym, mającym szczególne znaczenie w twórczości artysty. Nieznane dotychczas dzieło wybitnego rosyjskiego mistrza bez watpienia zasługuje na uwage koneserów malarstwa oraz badaczy jego twórczości. Mamy nadzieję, że „Portret w twierdzy" na nowo przypomni postać utalentowanego przedstawiciela rosyjskiej akademickiej szkoły XIX wieku, jakim bez wattpienia był Aleksiej Iwanowicz Korzuchin i przyczyni się do lepszego poznania jego twórczości oraz warsztatu malarskiego.

\section{Summary}

\section{"The portrait in the stronghold" (on unknown painting of A. I. Korzuchin)}

In the year 2006 in the one of the Polish antiquaries private collector has bought the painting of the young sad girl enclosed in the cell. It was executed on canvas of $72 \times 52 \mathrm{~cm}$ size, signed and dated at the right edge of the painting in its centre - „Корзухинъ 1875” - name in Russian in Cyrillic alphabet. For the reason of the state of preservation the painting was conserved and restored.

The paper outlines the history of the artist - Aleksiej Iwanowicz Korzuchin (1835-1894) famous in the past, at present a bit forgotten, yet still being one of the significant Russian painters specialized in genre scenes and portraits. The painting was analyzed in the aspect of its style. It example of the representative current of the 19th century Russian painting depicting decline of the feudal world and representing issues of the social equality. Further on the state of preservation as well as technical structure as well as technology were presented in detail, enabling statement of authenticity. At last the conservation-restoration treatment is described. 


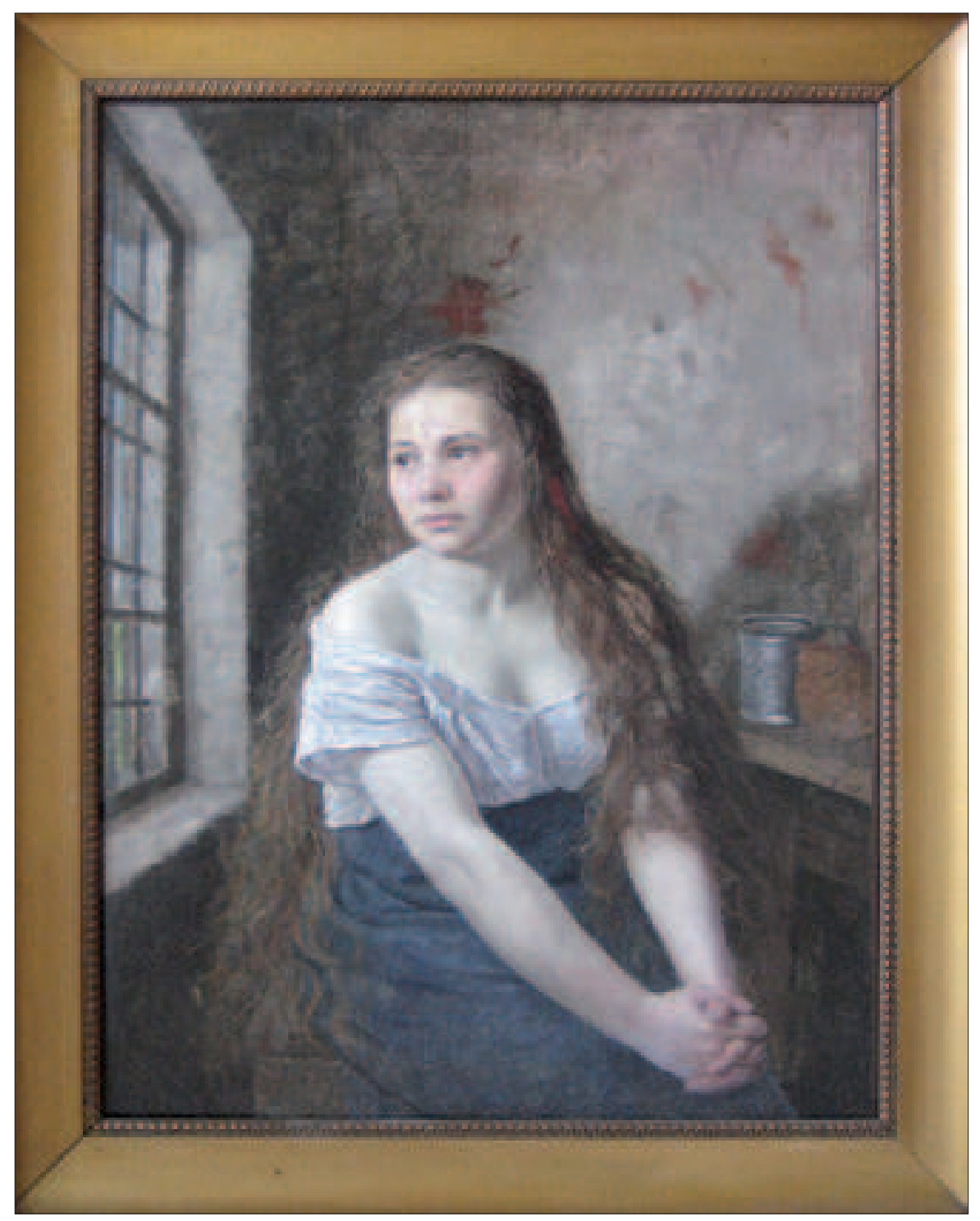

Il. 1. A. I. Korzuchin, „Portret w twierdzy”, 1875 (fot. D. Markowski) 


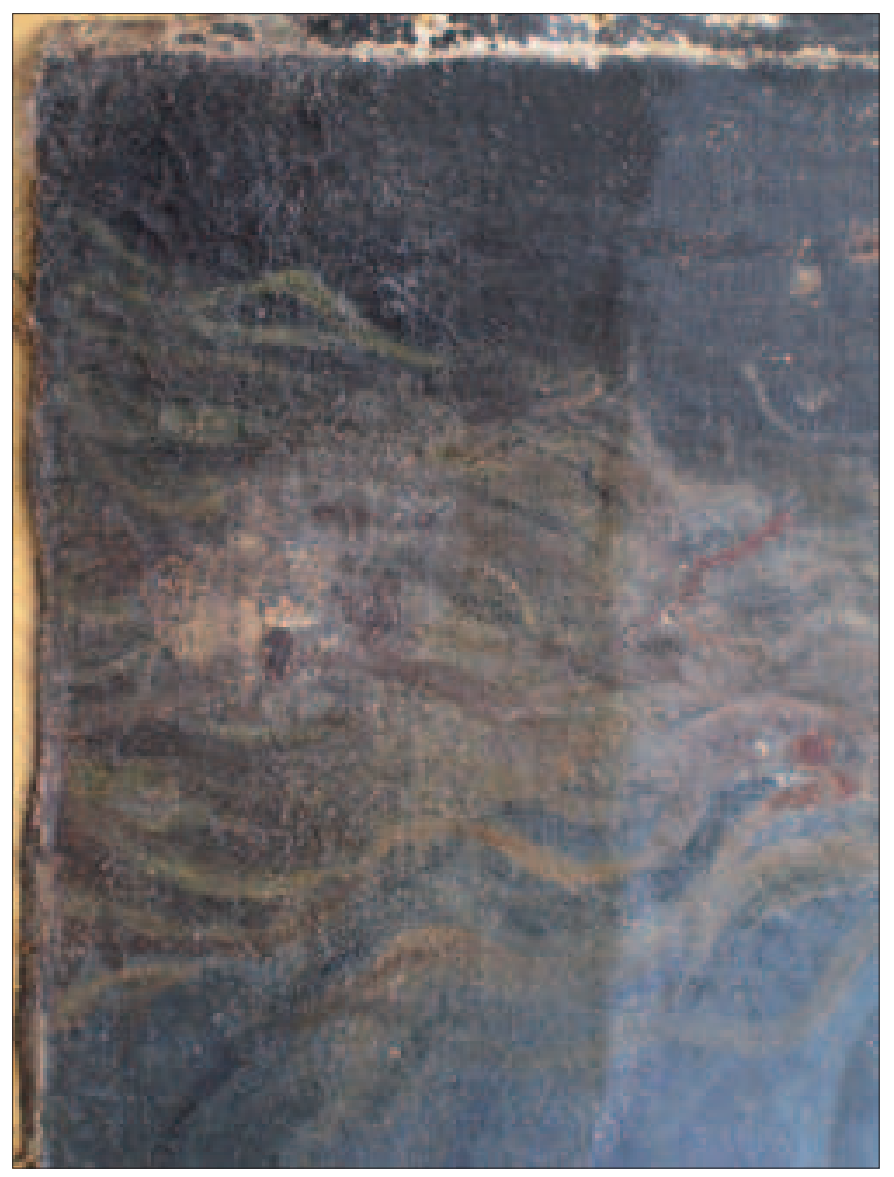

Il. 2. Fragment lica obrazu. Na zdjęciu widoczny zły stan zachowania obrazu przed konserwacja - przemalowania w partii włosów (fot. D. Markowski) 


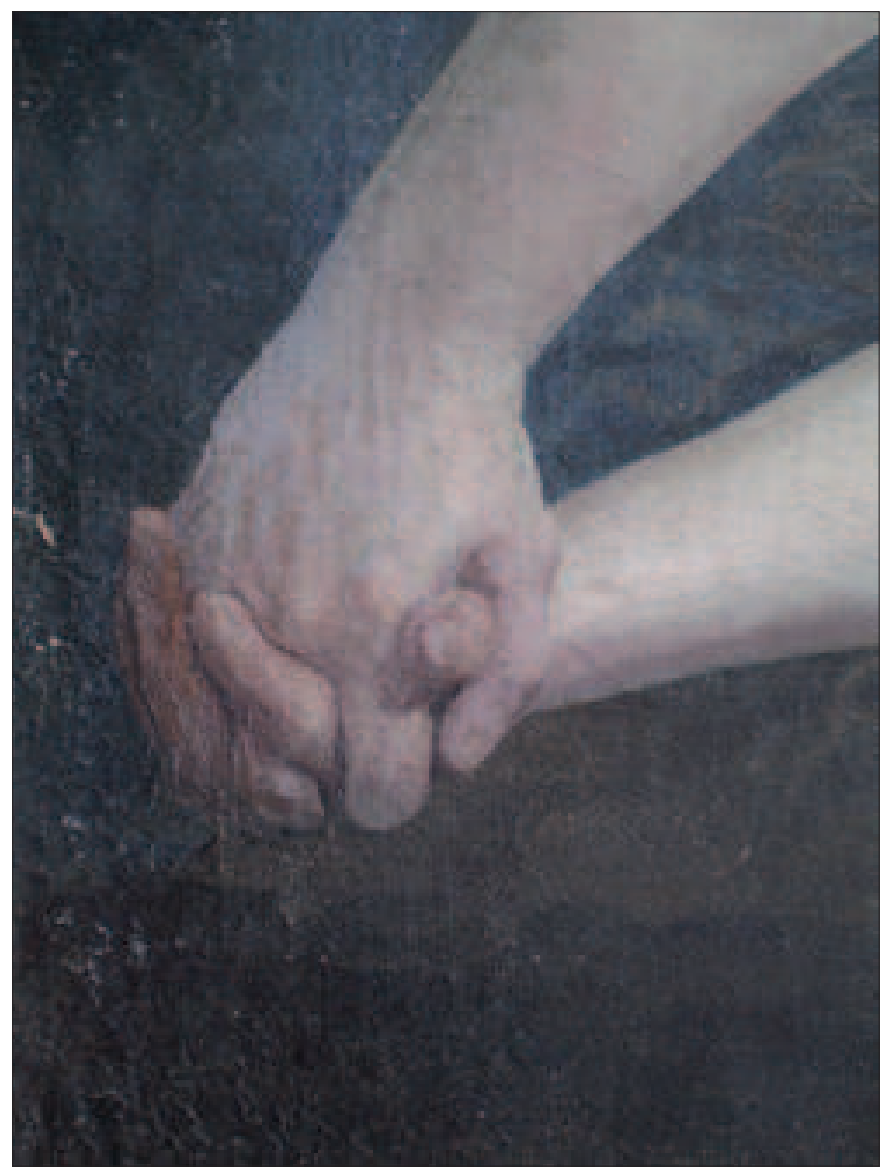

Il. 3. Fragment lica obrazu. Na zdjęciu widoczne przemalowania oraz spękania występujące głównie w partiach wtórnych uzupełnień ubytków zaprawy i warstwy malarskiej (fot. D. Markowski) 


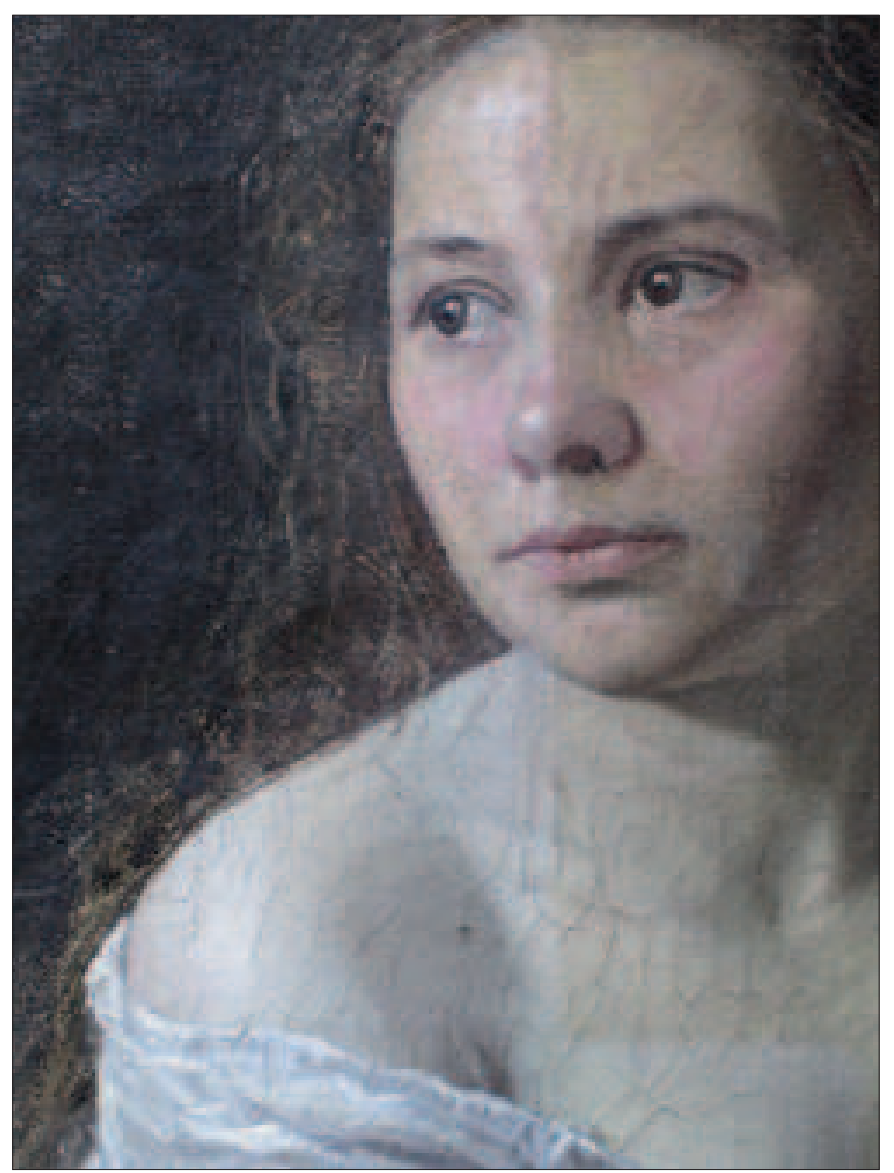

Il. 4. Fragment lica obrazu w trakcie usuwania wtórnego werniksu (fot. D. Markowski) 